Mavi Atlas, 5(1)/2017: 135-159.

Araştırma Makalesi | Research Article

Makale Geliş | Received: 08.04.2017

Makale Kabul | Accepted: 15.04.2017

Doi: 10.18795/gumusmaviatlas.307345

Fatih UYAR

Arș. Gör. | Res. Assist. Gümüşhane Üniversitesi, Edebiyat Fakültesi, Türk Dili ve Edebiyatı Bölümü, Gümüşhane-Türkiye Gümüşhane University, Faculty of Letters, Dep. of Turkish Language and Literature, Gümüşhane-Turkey

fatihauyar@hotmail.com

\title{
Monolojik Söylem Romancısı Olarak Halide Edip: Vurun Kahpeye ve Zeyno'nun Ŏglu Örnekleri
}

$\ddot{\mathbf{O z}}$

Romanın Türk Edebiyatı'na girişi Tanzimat dönemine rastlar. Edebiyatın toplumu eğitme ve dönüştürme misyonuyla işlevsellik kazandığı bu süreçte roman da bundan etkilenir. Toplumsal olayları ve toplumdaki tüm katmanları yansıtabilme imkânına sahip olan roman, yazarın üslubuna ve yazıldığı döneme göre yön kazanır. Cumhuriyet Dönemi romancılarından Halide Edip, imparatorluktan ulus devlete geçiş döneminde, toplumun şekillenmesi ve milli kimlik inşasında belli bir misyon üstlenen bir romanc1 olarak görülür. Eserlerinde yeni bir ulus yaratma bilinciyle hareket eden yazar, Kurtuluş Savaşı, Yunan İşgali gibi vakaları eserlerinde konu olarak işlerken eserlerini "monolojik söylem” olarak nitelendirilebilecek bir yaklaşımla inşa eder. Bu çalışmada, ilk aşamada Bahtin'in romanda çokseslilik kuramı, ikinci aşamada ise Thompson'un anlam inşa etme yöntemleri olarak geliştirdiği metodoloji bağlamında Halide Edip'in Vurun Kahpeye ve Zeyno'nun Oğlu romanları tahlil edilecektir. Böylelikle Halide Edip'in üslubu ve söylemi arasındaki etkileşim ortaya konacaktır.

Anahtar Kelimeler: Halide Edip Adıvar, Çokseslilik, Üslup, Söylem, Monolojik.

\section{Halide Edip as a Novelist who has Monologic Discourse: Vurun Kahpeye and Zeyno'nun Oğlu Samples}

\begin{abstract}
The introduction of the novel into Turkish literature coincided with the Tanzimat period. In this period, literature gains functionality through the mission of educating and transforming society, the novel was also affected by this mission. The novel that has facility to reflect all stages of society and social events, takes route according to its writer's style and the period when it was written. Halide Edip as a novelist of the republic period is seen as a novelist who undertook certain missions for the formation of the society and construction of the national identity in the transition period from emperorship to nation state. The writer who wrote with the conscious of creating a new nation builds her works with the approach which is qualified as a "monologic discourse" and she wrote on the cases like "Independence War" and "Greek Occupation". In this study, Halide Edip's Vurun Kahpeye and Zeyno'nun Oğlu novels are going to be analyzed in the context of firstly Bakhtin's polyphony theory in novel and secondly the methodology as the means of construction of meaning developed by Thompson. Thus it is going to be explained the interaction between Halide Edip's style and discourse.
\end{abstract}

Keywords: Halide Edip Adıvar, Polyphony, Style, Discourse, Monologic. 


\section{Giriş}

Roman, insanı ve toplumu merkeze alan toplumsal olayları, insana özgü durumları, dünya görüşlerini, toplumun sosyal zevklerini sanatsal bir yapıda birleştirmeye elverişli bir edebi türdür. Sanatkâr, yaşamış olduğu toplumun bir üyesi olarak kurmaca bir tür olan romanda, kişiler, olay, zaman, mekân gibi unsurları kullanarak bir eser meydana getirir.

Romanın ortaya çıkışı "edebiyat tarihçilerinin genelinin görüşüne göre, burjuvazinin yükselişine bağlanır.” (Seyhan 2004: 45). Batı'da ortaya çıkan romanın Türk Edebiyatı'na girişi ise Tanzimat dönemine rastlar. Batılılaşma programlarının gerçekleştiği bir dönemde, edebiyat da batılılaşma rotasında bir görev üstlenerek yeni bir tür olan roman aracılığıyla topluma hitap etme olanağı yakalar. Tanzimat ile birlikte “edebiyat, Türkiye'de er geç tahakkuk edecek siyasi ve içtimai bir inkılabın öncülüğüne soyunur.” (Banarlı 2004: 859). "Türk romanı Batılılaşma sürecinde olan bir toplumun arayışının türüdür. Girilen yeni medeniyet dairesinde yeni bir varoluş felsefesinin etkisinde kalan Türk romancıları, hem kendi öz değerlerini bulmak, bu değerleri bir perspektif içinde sentezlemek, hem de Batı medeniyeti dairesine girmiş olmanın mecburiyetlerini yerine getirerek bu yeni anlatı türünün örneklerini vermeye çalışır." (Tüzer 2010: 61).

Osmanlı Devleti'nin yıkılması ve akabinde Türkiye Cumhuriyeti'nin kuruluşuyla devam eden süreçte, ulus olma sürecinin ağırlık kazanmasıyla imparatorluktan ulus devlete evrilen toplumsal bir yapı ortaya çıkar. Bu süreçte, Tanzimat dönemi edebiyatçılarının toplumu eğitime misyonu üstlenme bilinciyle hareket etmesi gibi, Cumhuriyet dönemi yazarları da kendilerine yeni bir ulus yaratma yolunda misyon biçerler. "Türk kültürünü yeniden yoğurmaya girişen Cumhuriyet, bireyi ve düşünceyi de kendi kalıpları doğrultusunda şekillendirme aracı olarak edebiyatı seçer.” (Karpat 2009: 129). Bu seçim sonucunda bir sanat eseri olma özelliği taşıyan edebi metin, "estetik unsurların ihmal edildiği bir edebiyat anlayışı haline gelir ve eserler bir fikrin savunucusu ve ideolojinin taşıyıcısı konumuna gelirler.” (Baş 2013). 
“Cumhuriyetin yükselen değerleri olan milliyetçilik, uygarlaşma, hurafelere çağdaş değerlerle karşı çıkma ve ulus olma bilincinin uyandırılması gibi konular, Cumhuriyet dönemi Türk romanının başat temalarını oluşturur.” (Gündüz 2009: 400). II. Meşrutiyet'in ilanından sonra roman yazarlığına başlayan Halide Edip Adıvar, Cumhuriyetin kuruluşundan sonra da yazmaya devam ederek ulus bilinci, kadın merkezli çağdaş aydınların mücadelesi, Batılılaşma-geleneksel değerler çatışması gibi konularla eserler meydana getirir.

Bu makalede Halide Edip'in Vurun Kahpeye ve Zeyno'nun Oğlu isimli eserleri iki aşamalı olarak ele alınacaktır. Öncelikli olarak Halide Edip'in bu romanları türün nitelikleri ve teknik yapının inşa ettiği söylem bağlamında işlevsel olarak ele alınacak, ikinci aşamada ise bu romanlara ideolojik niteliği veren anlam inşa etme yöntemleri tahlil edilecektir.

\section{A-Türün Nitelikleri Bağlamında Halide Edip Romanlarına Bakış}

$\mathrm{Bu}$ bölümde Bahtin'den hareketle edebiyat sanatı incelemesi yapılırken "soyut bir 'biçimsel' yaklaşım ile aynı ölçüde soyut 'ideolojik' yaklaşım arasındaki kopukluğu giderebilmek için” (Bahtin 2014: 36) romanın bir tür olarak hangi nitelikleri taşıması gerektiği ortaya konulacak ve Halide Edip romanlarındaki söylem bu çerçevede incelenecektir.

Roman bir bütün olarak "biçem bakımından çok biçimli, söz ve ses bakımından çeşitlilik sergileyen bir fenomen olarak roman araştırmacısını farklı dilbilimsel düzeylere yerleştirilmiş olan ve farklı biçimsel denetimlere tabi olan çeşitli heterojen biçemsel bütünlüklerle karşı karşıya bırakır.” (Bahtin 2014: 36). Bahtin, romanın "sanatsal olarak düzenlenmiş bir toplumsal söz tipleri çeşitliliği (hatta bazen de diller çeşitliliğii) ve bireysel sesler çeşitliği olarak tanımlanabileceğini” (2014: 37) söylerken dilin katmanlaşma imkânının romanda yer bulması gerektiğini vurgular. Bu katmanlaşma "herhangi tekil bir ulusal dil, içsel olarak toplumsal lehçelere, tipik grup davranışlarına, mesleki jargonlara, tür dillerine, nesillerin ve yaş gruplarının dillerine, 
taraflı dillere, otoritelerin, çeşitli çevrelerin ve geçici modaların dillerine, günün hatta saatin özel sosyo-politik amaçlarına hizmet eden dillere (her günün kendi sloganı, kendi sözcük dağarcı̆̆ı, kendi vurguları vardır) bölününceye dek gidebilir.” (Bahtin 2014: 37). Roman için vazgeçilemeyecek ön koşul bu "iç katmanlaşmayı yansıtmak ve söz tiplerinin toplumsal çeşitliliği aracılığıyla ve böylesi koşullar altında serpilen farklı bireysel sesler aracılığıyla temalarının tümünü, kendisinde betimlenen ve ifade edilen konuların ve fikirlerin dünyasının tümünü orkestralamaktır.” (Bahtin 2014: 37). Bir tür olarak "romanı farklı kılan” özelliğin dilsel katmanlaşmanın bütün unsurlarının romana girmesi olarak belirten Bahtin (2014: 76), ses çeşitliliklerinin romana girerek yapılanmış bir sanatsal sistem oluşturacak şekilde örgütlendiğini belirtir. Bahtin'in bütün seslerin sanatsal bir yap1 içerisinde örgütlenerek romana girmesi gerektiğini savunduğu çokseslilik kuramı, romanın içerisinde kendi özel düzenini tesis etmesi ve yazarın tasarladığ1 konuyu orkestralayarak benzersiz bir sanatsal sisteme dönüştürmesi bakımından yazara ve metne biçimsel imkân sağlar.

Romana girerek "sanatsal bir işleme tabi olan toplumsal ve tarihsel tüm sesler, yazarın topumsal-ideolojik konumunu dışa vuran yapılanmış biçemsel bir sistem oluşturur.” (Bahtin 2014: 76). Oluşan bu sistem çerçevesinde yazar bir üslup geliştirerek metni kurgular.

Halide Edip romanlarını incelerken çokseslilik kuramı bağlamında, yazarın bütün sesleri eserlerinde yansıtıp yansıtmadığına bakılacaktır. Bu bölümde, yazarın kahramanları karşısında konumu ve üslubunda çoksesli mi monolog mu olduğu incelenecektir.

\section{1-Kahraman ve Yazarın Konumu}

Bahtin'e göre romanda esas olan, "kahramanın dünyada nasıl göründüğü değil, öncelikle dünyanın kahramana nasıl göründügü ve kahramanın kendi kendisine nasıl göründüğüdür.” (2004: 97). Dünyaya ve kendisine bakış açısı olan kahraman, kendisini çevreleyen gerçekliği ve kendi benliğini değerlendirmesini sağlayacak bakış açısıyla 
çizilmişse kurmaca eser bütün sesleri yansıtabilir. Eğer yazar, kurmaca eserdeki kahramanları nesneleştirmiş ve kendi söylemi çerçevesinde şekillendirmişse kahraman kendi bakış açısı ile metinde var olamaz.

Kurmaca metinde keşfedilmesi ve karakterize edilmesi gereken şey, "kahramanın özgül varoluşu, sabit imgesi değil, tam da bilincinin ve öz-bilincinin toplamı, nihayetinde de kahramanın kendi dünyasına ve kendine dair son sözüdür." (Bahtin 2004: 98). "Kahramanın bilinci ve öz-bilinci ile eserde karakterize edilirken kahramanın toplumsal konumu, sosyolojik ve karakterolojik olarak tipik olma derecesi, mizac1, manevi profili ve hatta fiziksel görünüşü” (Bahtin 2004: 98), yani kahraman yaratmada yazara yardımcı olacak bütün her şey dikkate alınmalıdır. Yazar, kendisi için yani kendi özel görüş alanı için kahramanın tek bir özsel tanımını, "tek bir kişilik özelliğini, en ufak ayırıcı özelliğini muhafaza etmemelidir.” (Bahtin 2004: 98).

Yazarın metni kurgularken kendisini veya kendi bilincini terk etmesi beklenmez. Ama ondan beklenen, başkalarının özerk bilinçlerini kendisinde barındırabilmesi için bilincini olağanüstü ölçüde genişletmesi, derinleştirmesi ve yeniden düzenlemesidir. Eğer "hayatın çoksesli doğası sanatsal olarak yaratılacaksa bu şarttır ve roman için kaçınılmazdır.” (Bahtin 2004: 123). Çünkü hayat, tek bir fikir veya ideoloji etrafinda şekillenmez. İnsan doğası da bu duruma elverişsizdir. Hayat bütün fikirlerin, duyguların, yönelişlerin iç içe geçtiği, karmaşık bir döngüye sahiptir. Bahtin'e göre roman, hayatın bütün yönlerini yansıtabildiği, romanın sanatsal işleyişinde örgütleştirerek bu şekilde kurmacasını zenginleştirebildiği ölçüde çoksesli olabilir. Toplumun tüm katmanlarında bulunan karakterler, kendi öz bilinçleri ve dünyaya bakışlarıyla anlatıda yer bulamıyorsa çoksesliliğin sağlandığını söylenemez.

Halide Edip'in Vurun Kahpeye ve Zeyno'nun Oğlu eserlerine bakıldığında yazarın kahramanlarına mesafeli durmadığı, onları olumlu ve olumsuz özellikleriyle anlatarak kahramanların gözünden kendilerinin ve dünyanın nasıl göründüğüne müsaade etmediği görülür. Yazarın kendi sesini yansıttı̆̆ı, kendi söyleminin temsilcisi olan karakterleri olumlu ve yüceltici bir tavırla karakterize ettiği görülür. Vurun Kahpeye romanında çağdaş bir öğretmen olarak İstanbul'dan Anadolu'ya gelen, tüm 
fedakârlıkları göze alan bir kadın tipi olarak yazarı temsilen karakterize edilen Aliye, olumlu ve pozitif yönleriyle anlatılır. Başkişi Aliye "yüzü henüz açılmayan bir gül goncasının mahcup kırmızılığının çekingen güzelliğini taşıyan, pembe, ince yüzü üstünde iki kocaman menekşe gibi siyah kirpikli gözleri, küçük bir çocuk burnu olan, biraz yumuşak ve kıvırcık siyah saçları itina ile örttüğü sıkı siyah başörtüsü olan" (Adıvar 2002: 1) son derece zarif, narin bir şekilde anlatılmaktadır. Herkesin kaçtığı, kimsenin görev yapmak istemediği bir yerde öğretmenlik yapması onun üstün yönlerindendir. Kendisine karşı kötülük düşünen köylüler, halk ve talebeleri hakkında hep iyi düşünen, onlara hep iyilik yapmayı kendisine görev edinen bir tiple karşılaş1lır. $\mathrm{Bu}$ olumlu anlatımın karşısında, yazarın olumsuz anlatımına örnek olarak Maarif Müdürü ile ilgili kısmı şöyle görülür:

Maarif Müdürü’nün toparlak siyah sakalı, bulanık sünepe ve mürai gözleri, hilekâr uzun yüzü altında iğrenç, ince dudaklı bir ağzı vardı (...) Maarif Müdürü'nün bulanık gözleri daha bulandı, burnu uzadı, bütün yüzü daha hilekâr ve kibirle riyakâr bir tevazuyu karıştıran tavrını aldı (Adıvar 2002: 5).

Halide Edip eserde, olumlu gördüğü ve kendi bakış açısına hizmet etmek için olumlu kurguladığı kahramanları, olumlu olarak ön plana çıkarma tekniğini Ömer Efendi, Tosun Bey, Gülsüm Hala kahramanları üzerinden de sürdürmektedir. Tosun Bey, Kuvay-1 Milliye komutanı olarak Yunanlara karşı büyük bir mücadele vermekte, Anadolu halkını fedakârca düşman istilasından korumaktadır. Halide Edip bunun karşısında ise Hacı Fettah Efendi, Kantarcıların Hüseyin Efendi'nin oğlu uzun Hüseyin Efendi, köylü kadınlar, köyün çocukları, Hatice Hanım gibi kahramanları olumsuz, ötekileştirici, nesneleştirici bir şekilde karakterize etmektedir.

Zeyno'nun Oğlu eserinde de Halide Edip, kahramanların gözünde bir dünyada değil, kendi bakış açısıyla inşa ettiği dünyada kurmacasını inşa eder. Kahramanlarını sınırlandırıcı, onların öz bilinçlerini yansıtmayan bir üslupla kurgulayan yazar, toplumun bütün kesimlerine ve seslerine bu eserde de yer vermez. Bu eserde Batı'ya tamamen teslim olmuş, taklitçi ve gösterişçi bir tip olarak resmettiği Mesture Hanım, batı hayranı olan ve hayatı tamamen gezmelerden, gösterilerden, partilerden ibaret bir 
tip olarak karşımıza çıkar. Kızını evlendirme sevdasına, kendisinden genç erkeklerle ilişki yaşamaya hevesli olan Mesture Hanım, Halide Edip'in şu betimlemesiyle tanıtılır:

\begin{abstract}
Mesture Hanım'ın başına sımsıkı sardığı kahverengi tül, yuvarlak yüzünü, tombul yanaklarını daha dolgun, daha kırmızı gösteriyor, biraz küçük ela gözlerinin kapaklarını şişiriyordu. Tam kaşlarının ortasından sarkan sarı bir lüle, şakaklarından dökülen tutam tutam kıvırcıklar başının umumi heyetini fazla süslü, nümayişkâr, bir et, saç ve renk yığını haline sokuyordu. Bununla beraber siyah sürmeleri arasındaki gözlerin kırıtmaya çalışan ifadelerinde, sun'i bir nezaketle büzülen pembe dudaklarında (...) (Adıvar 2010: 31).
\end{abstract}

Vurun Kahpeye eserinde olduğu gibi bu eserde de olumsuz kahramanların yanında olumlu, yazarın fikri ve ideolojik söylemine hizmet eden olumlu kahramanlara yer verilir. Mazlume, bu eserin olumlu olarak karakterize edilen kahramanlarından birisidir. Mazlume, annesinin tüm baskılarına ve onu asrileştirme çabalarına rağmen büyükannesinin gelenekçi bakışından dolayı annesinin taklitçi yaşantısına heves etmeyen, hatta onunla alay eden bir karakter olarak karşımıza çıkar. Büyükannesinin tesiri, onu sun'i olmaktan muhafaza eder, Darülfünun'da asriliğin o, ismini bilmediği genç doktorun dediği gibi, Avrupa medeniyetini batıracak olan çirkin ve ucuz tezahüratından kurtarır, genç kızda tabiliğe, serbest düşünceye karşı bir temayül uyandirır (Adivar 2010: 35).

İki eserde de kahramanlar kendi bilinç ve şuurlarıyla değil, yazarın istediği şekilde var olurlar. Yazar, kahramanlarına söz ve eylem alanı bırakmayarak onları nesneleştirir. Hayatın belirli bir sosyal kesitinden alınarak kurgulanan roman, farklı dünya görüşlerinin, hayat tarzlarının orkestralandığı bir evreni temsil etmez.

Yazarın eserlerin bazı yerlerinde, olumlu göstermek istediği karakterleri, kahramanlarının ağzından olumladığı da görülür. Vurun Kahpeye eserinde Aliye, Ömer Efendi’nin 'tasvir gibi bir gız, bizim Rahmetli Emine’yi andım, o 1rz düşmanı papaz zıfatlı Müdür gıza hemen goz attı, gız öyle aslan yürekli ki (...)” (Adıvar 2002: 6) cümleleriyle övülür. Zeyno'nun Oğlu eserinde Saffet ise Mazlume'nin, “şimdi öyle konuşuyor, çok alimane konuşuyor ama meselenin ruhu biraz büyükannemin dediklerine varıyor, neyse, ben ağzı açık dinledim, azıcık da korktum fakat biraz sonra 
ahbap olduk, hatta bir gün sonra yine bir tıbbiyelinin evinde bir çayda bulunduk, beraber dans bile ettik" (Adıvar 2010: 47) sözleriyle övülür.

Yazarın kahramanları karşısında konumu, Bahtin'in kuramında öne sürdüğü konumdan oldukça uzaktır. Kahramanlar bu eserlerde, kendi eylemleri ve fikirleri ile değil, yazarın ya da onun seçtiği kahramanların gözünden tanıtılırlar. Batılılaşmagelenek çatışması, köylü-şehirli kutuplaşmasında yazar, bazı kahramanlarını kendi fikrini temsilen konumlandırırken bazılarını da tam karşıt şekilde olumsuz olarak karakterize eder. Yazarın sesini temsil eden yazarların sesi, karşıt görüş kahramanların sesini bastırır. Kahramanların kendilerini kendi gözleriyle tanımlamalarına yer verilmediği gibi, kendi dünyalarına sahip bilinçlilikte de olmadıkları görülür. Yazar, kendi fikrine karşıt tanıttığı kahramanları ötekileştirici ve nesneleştirici üslubuyla sınırlandırır, şeyleştirir. Kahramanlar, sun'ilikten kurtulamayarak yapaylaşır ve sınırlandırıldıkları çizginin ötesine geçemezler. Farklı dünya görüşlerine yer verilmediği gibi, olumlu veya olumsuz tanıtılan kahramanların kendi iç dünyalarındaki çelişkiler, çatışmalar ve derinlikli tahlillere de yer verilmez. Halide Edip romanlarının kahraman yazar konumlandırması bakımından hayatın çoksesli doğasını yansıtmadığı söylenebilir.

\section{2-Halide Edip Romanları: Çoksesli mi, Monolojik mi?}

Bahtin, romanı, diğer türlerden ayıran en önemli özelliğin çoksesli hayatın doğasını kurmaca dünyada yansıtabilmesi olarak görür. Çoksesliliğin gerçekleşebilmesi, yazar ile kahraman arasındaki konumlandırma biçimi kadar, "toplumsal-ideolojik dillerin edebi metne yansıtılması ve daha da önemlisi tüm dil, üslup ve söylemlerin diyalojik etkileşim ortamına ait bir konum içinde sunulmuş olması ile mümkündür." (Baş 2013: 1003-1032).

Bahtin, çoksesliliğin sağlanmasına katkı sunan bir kavram olarak diyalojik etkileşim tabirini kullanır. "Diyalojik etkileşimden her söylemin doğal yönelimini, sözcügün nesneye uzanan tüm rotalar ve doğrultularda her an etkileşim alanında olmasını ve her sözcüğün bir yanıta yöneldiğini ve öndelediği yanıtlayıcı sözcükten 
derinlemesine etkilenmekten kaçınamaz olduğunun göz önünde bulundurulmasını kasteder.” (Bahtin 2014: 56). Romanda ortaya çıkacak diyalojik yönelim ise kahramanların kendi sesleri, fikirleri ve öz bilinçleriyle bulunması ve karşıt değerlerle kendi iç alemleriyle hesaplaşmalarıyla gerçekleşir. Yazarın sesinin hâkim olduğu durumlarda ise diyalojik etkileşimden değil, monolojik bir söylemden söz edilebilir. Bahtin, yazar-monologcunun yapıta dahil ettiği söylem tiplerinin ne olursa olsun yazarın niyetinin ve değerlendirmelerinin romandaki tüm sesleri bastırması ve onları hakimiyeti altına alması gerektiğini (2004: 279) söyleyerek monolojik söylemi tarif eder. Monolojik romanda belli bir söylemde veya yapıtın bir bölümünde ötekilerin tonlamalarının yoğunlaştırılması bir oyundur yalnızca; yazarın kendi dolaysız ve süzgeçten geçirilmiş sözünün olabildiğince güçlü tınlaması için izin verdiği bir oyundur. "Tek bir söylem içinde iki ses arasındaki söylemi sahiplenmeye veya onun üzerinde hâkimiyet kurmaya yönelik her türlü mücadeleye peşinen karar verilir; ortada gerçek bir mücadele değil, sadece mücadele görüntüsü vardır; yazarın anlamlandırıcı yorumlarının hepsi er ya da geç tek bir konuşma merkezinde ve tek bir bilinçte toplanır; tüm vurgular tek bir seste birleştirilir.” (Bahtin 2004: 279). Bahtin, monolog söylemin yerine çiftsesli söylemin ve çok yönlü vurguların en uç boyutta romanda etkin hale gelmesini savunarak monolojik romana karşı çıkar.

Genelde Cumhuriyet romanı, özelde ise Halide Edip romanları esas alındığında, monolojik söylemin esere hâkim kılındığı görülecektir. Yeni bir ulus yaratma düşüncesini kendisine vazife gören Cumhuriyet ideolojisi, farklı seslerin fikirler sunmasını tehlike olarak görüyordu. Halide Edip, Yakup Kadri ve Reşat Nuri gibi bu ideolojinin romandaki temsilcileri de yeni bir ulus yaratma düşüncesini kendilerine görev saydılar. Haliyle bu ideolojik söylemin romana yansıması, estetik kaygıların ihmal edilmesi, farklı düşünce/eylem/kanaatlere yer verilmemesine yol açar. $\mathrm{Bu}$ makalede incelenen Vurun Kahpeye ve Zeyno'nun Oğlu eserlerinde Halide Edip, farklı seslerin ve fikirlerin yer aldığı çoksesli bir söylemi değil, monolojik bir söylemi tercih eder. Roman kahramanları arasındaki diyaloglarda yazarın fikrini savunan 
kahramanların fikirlerine yer verilirken ötekileştirilen kahramanların düşünceleri görülmez.

Zeyno'nun Oğlu eserinin kahramanlarından Saffet'in, Muhsin Bey ile arasında geçen diyalogda kahramanlar sadece soru sorarlar. Farklı fikirleri beyan etme, Saffet'in düşüncelerine karşı çıkma olanağı kahramanlara tanınmaz:

Hayatın derinliğine başları değen gençlik, yalnız bugünkü dünyanın gençliğii! Yalnız dinin, felsefenin ve her günkü hayatın en büyük esası insanların mütekabil bağlarını geniş bir görüşle düzenlemek olduğunu bilmiyor. Bunların kuracağ1 "İnsanlar Cemiyeti" ne "Cemiyet-i Akvam" ne de "Sovyetler Şurası" gibi milletlerin yahut sınıfların birer inhisarından, müşterek menfaatli şirketinden ibaret olacaktır. Bunlar, insanlar arasına konan her engeli, insanları gözleri bağlı birbirini boğazlamaya sevk eden katil sistemini yıkacaklardır. Bunlar (...)

Hasan Bey atıldı:

-Sen milliyetperversin sanıyordum. Dönüp dolaşıp bize beynelmileliyet ifade eden bir felsefeyi yutturmaya çalışıyorsun.

Saffet birdenbire güldü:

-Türk Ocağı'nın en eski azasındanım, azizim. Milletimin kendini ifade etmek için kullandığı her vasıta, benim için en güzel, en sevimlisidir. Bunların kırkıncı asırda bile değiş̧mesini istemem. İyi Türk milliyetperveri bence, başka milletlerin yüzünü ucuz bir maske halinde suratına takmayan adamdır. Bence o, kendi simasını muhafaza eden, fakat dünyanın yeni revşinde, insanlığa aklı ile kalbi ile sükun ve kudretiyle nümune olan Türk’tür (Adıvar 2010: 250-251).

Saffet'in bu konuşmasından sonra, ne Hasan Bey ne de Muhsin Bey cevap vermezler ve kendi görüşlerini savunmazlar. Diyalojik etkileşimin hâkim olduğu romanda, fikirsel bir tartışmanın olması veya karşıt görüşün jest ve mimikleri ile bu fikre katılmadığını belirttiği imalar beklenir. Fakat monolojik söylemin hâkim olduğu bu romanda, kahramanlar, yazarın da fikrini temsil eden bu fikirlere karşı durabilme yeteneğinden mahrum karakterize edilmişlerdir.

Vurun Kahpeye eserinde Hatice Hanım ile Tosun Bey arasında Aliye hakkında geçen diyalogda da benzer bir durumla karşılaşılır. Hatice Hanım, Aliye’nin çocukları yüzü gözü açık şekilde çarşıdan geçirdiğini söyleyince yazar araya girerek Kuvay-1 
Milliye kumandanlarının müşterek ve bariz bir hususiyetleri olduğunu belirterek çavuşundan paşasına kadar yeni bir şeyler isteyen, hiç mutaassıp olmayan, mühim surette yeni bir kadın tipine taraftar olduğunu belirtir (Adıvar 2002: 31). Tosun Bey’in ifadeleriyle bu ifadesini güçlendirir:

-Muallime Hanım, namus kadının yüzünü açıp açmamasında değildir. Din de peçe demek değildir. Öyle kapalı kadınlar vardır ki kapı arasından her türlü rezaleti yaparlar. Onun için yeni Hoca Hanım'a yüzü açık diye kasabanın hücuma hiç hakkı yoktur. Çocukları İstanbul usulü güzelce okutan herhangi bir hoca hanıma birisi yan bakarsa biz onun terbiyesini (...) (Adıvar 2002: 31).

Hatice Hanım, Tosun Bey’in bu sözlerine biz de eski İstanbulluyuz diyerek geri adım atar ve bu genç kızların bazen öyle iyileri olur ki diyerek monolojik söylemin zaferini ilan eder.

Vurun Kahpeye eserinde Hacı Fettah Efendi, Kantarcıların Uzun Hüseyin Efendi ve Maarif Müdürü'nün her akşam Yunan kumandanıyla beraber içki sofrasında âlem yaptığı belirtilerek bu kahramanlar yazarın monolojik söylemiyle mahkûm edilir. Bu kahramanlara söz hakkı tanınmayarak yazarın sınırlandırdığı çerçevede hapsedilirler.

Zeyno'nun Oğlu eserinde Mesture Hanım ile kızı Mazlume dünya görüşleri olarak birbirlerine oldukça ters bir yapıda karakterize edilirler; hatta o derece ki eskiyeni kutuplaşmasının izleri görülebilir. Fakat roman boyunca bu ikili arasında bir fikir tartışmasının cereyan etmemesi, eserin derinlikli bir tez üretmesine engel olur. Mesture Hanım ile Zeyno arasında süren gizli gerilim de söz ve fikirsel bağlamda yer bulamaz. $\mathrm{Bu}$ ikili çatışmaların diyaloglar halinde yer bulamaması, eserlerin diyalojik roman özelliği kazanmasına engel olur.

Halide Edip'in bu romanları Bahtin'in açıkladığı çoksesli romandaki yazarın oluşturması gereken diyalojik konuma uygunluk göstermez:

Çoksesli romanda yazarın kahraman karşısındaki yeni sanatsal konumu eksiksiz gerçekleştirilmiş ve baştan sona tutarlı bir diyalojik konumdur; kahramanın bağımsızlığını, iç özgürlüğünü, sonuçlanamazlığını ve belirlenemezliğini onaylayan bir konumdur. Yazar için kahraman "o" değildir, "ben" de değildir ama tamamen meşru bir "sen"dir yani bir diğer öteki özerk "ben"dir ("sen varsın”) (Bahtin 2004: 117). 
Halide Edip, romanın içerisinde "ben” olarak durmaya çalışır ve kahramanlarını bu üslupla karakterize ederek diyalojik yönelimden uzaklaşır. Yazar, teksesli tutumuyla olumsuz anlattığı karakterleri ötekileştiren, gözden düşürücü bir üslup takınarak romanda monolojik bir havayı hâkim kılar.

\section{B-Halide Edip Romanlarında İdeolojik Söylem}

Edebi metnin bir ideolojinin ve fikrin savunucusu olabileceği bazı edebiyat kuramcılarına göre doğru değildir. Fakat Pospelov gibi bazı edebiyat kuramcıları da "bir ülke ya da bir dönem için karakteristik olan boyutların, yazarın gerçekliği nasıl değerlendirdiğinde dile geleceğini ve yazarın her zaman belli bir toplumsal katmanın kişisi olarak toplumsal olaylarda, ya katılarak ya da hatta yönlendirici olarak eserlerinde dile getirdiği toplumsal idealler için saf tutacağını söyler." (Pospelov 2014: 28). Bahtin de monolojik söylemin hâkim olduğu metinleri ele alırken yazarın kendi ideolojik söyleminin hâkim kılınması adına böyle bir yöntemin tercih edildiğini ifade eder. Yazar gibi, edebi metin de yazıldığı toplumun günlük yaşamından, siyasi olaylarından, toplumsal meselelerinden etkilenir. Edebi bir metni yazılmış olduğu toplumdan soyutlamak, eserin zihni arka planının göz ardı edilmesini beraberinde getirir.

Halide Edip Adıvar, Cumhuriyetin kuruluşundan sonra yazdığı Zeyno'nun Oğlu ve Vurun Kahpeye romanlarında, gerçekleşmesi için mücadele verdiği ideallerin hâkim olduğu bir anlam alanı inşa eder. Edebi bir metinde ideolojik söylemin inşa edilmesi konusunda Althusser bu söylemin "bir gerçekliği betimlemekten çok, bir istek, bir umut ya da bir nostaljiyi ifade" (Eagleton 1996: 234) şeklinde ortaya çıktığını belirtir.

İdeolojik söylemin sembolik biçimlerle metne dâhil edilebileceğini savunan John Thompson, sembolik biçimler vasıtasıyla anlam inşa edilebileceğini söyler. Thompson’un sembolik biçimlerden kastı “özneler tarafından üretilen ve onlar/başkaları tarafından kabul edilen geniş bir eylemler ve sözceler, imgeler ve metinler yelpazesidir." (Thompson 2013: 76). Özne/Yazarın anlam inşa etme sürecinde kullandıkları ideolojiyi işleyiş kiplerini beş başlık altında toplayan Thompson, bu beş 
kipin ideolojinin faaliyet gösterebileceği tek biçimler olduğunu söylemez aksine bu kiplere bazen farklı kiplerin de eklenebileceğini, hatta bu beş kipin bazen aynılaşarak birleşebileceğini de söyler. Thompson beş yöntemi şu başl1klar altında toplar: "1Meşrulaştırma; 2-Taslama; 3-Birleştirme; 4-Parçalanma; 5-Şeyleştirme”.

\section{Meşrulaştırma}

Sembolik biçimlerde meşrulaştırma süreci, özne tarafından "meşru, adil ve desteklenmeye değer olarak temsil edilenin" (Thompson 2013: 77) iknaya dönük yapılar halinde sunulmasını ön görür. Hikayeleştirme, akli zemine oturtma ve geleneksel temeller üzerine inşa edilen anlam yapısı herkesin kabul edebileceği, onaylayacağı bir şekilde sunulur. Sembolik biçim üreticisi "bir dizi toplumsal ilişki veya kurumu savunmaya ya da haklı çıkarmaya dönük anlam alanı oluşturarak" (Thompson 2013: 77) çalışır. Tarihsel ve toplumsal olaylar hakkında özne tarafından kabul edilen ideolojik söylem, okuyucu/dinleyici üzerinde aidiyet bilinci sağlayacak boyutlarda inandırıcılık oluşturabilecek şekilde anlatılır. İstisnai durumlar genelleştirme yoluyla genele hükmedilir ve desteklenen fikrin inandırıcılığı arttırılır.

Halide Edip, Vurun Kahpeye eserinde Kurtuluş Savaşı esnasında Anadolu'da meydana gelen işgalleri ve özellikle Yunanlar tarafindan gerçekleştirilen işgal zamanında topraklarımızda yaşanan olaylar esnasındaki vakaları hikayeleştirme yoluyla eserine dayanak oluşturur. Halide Edip, Vurun Kahpeye eserinde hikayeleştirme yönteminden hareketle Hacı Fettah Efendi karakteri üzerinden bir din adamının Yunanlarla işbirliği yapmasını monolojik bir şekilde ele alarak anlam alanı oluşturur. Hacı Fettah Efendi, Ömer Efendi ile yaşadığı bir arsa meselesinden dolayı Yunanlarla işbirliği yapabilecek ölçüde hain ve işbirlikçi bir şekilde tanıtılır. Yazar, dünyevi endişeler sebebiyle bir insanın her şeyi yapabileceği, hatta düşmanlarla işbirliği dahi yapabilecek bir duruma yönelebileceğini akli zemine oturtarak meşrulaştırma yöntemini uygular. Kantarcıların Hüseyin Efendi ise Aliye'ye aşık olması ve sırf onu elde etmek amacıyla Yunanların köyü işgal etmesi ile ona sahip olabilmeyi hedefleyen ihtiras 
sahibi bir insan olarak karşımıza çıkar. Yazar eserde monolojik bir yaklaşımla kendi bakış açısını, iki kahraman üzerinden hikayeleştirme yöntemiyle meşrulaştırmaya çalışır.

Zeyno'nun Oğlu eserinde ise Cumhuriyetin ilanından sonra ortaya çıkan Kürt isyanı ve Diyarbakır'da yaşayan halkın yaşantısı öyküleştirilerek metne dâhil edilir. Yazar burada da Şeyh M. kahramanı üzerinden, hükümete karşı çıkarılacak bir Kürt isyanında Haso çocuğun alet edilmesini hikayeleştirir. Şeyh M., Muhsin Bey ve diğer askeri vazifelileri takip etmek üzere Haso çocuğu dini eğitim verme bahanesiyle yanında tutuyor gösterilir. Bu hikayeleştirme yoluyla Şeyh M. ve çevresinde bulunan tarikat mensuplarının yaşantıları teksesli bir bakış açısıyla yerici ve ötekileştirici bir şekilde ele alınır.

Yazar genelleme yoluyla da eserlerde olumsuzladığı karakterler konusunda hedef kitleyi ikna etme amacına sık sık başvurur. Vurun Kahpeye'de Hacı Fettah Efendi, Kantarcıların Uzun Hüseyin, Maarif Müdürü, Hatice Hanım, köylü kadınlar, eşraf çocukları yazarın olumsuzladığı kişiler olarak görülür. Bu olumsuz kahramanların ortak yönü menfaatçi, ikiyüzlü, güven vermemeleri, güç karşısında eğilmeleri ve onursuz olmalarıdır. "Eşraf çocuklarının ekserisi cılız, fena bakılmış, sümüklü, kirli, fakat mütehakkim ve ahlaksızdı." (Adıvar 2002: 20) gibi olumsuz ve genelleyici ifadeleri yazarın monolojik bakışını yansıtmaktadır. Aliye'nin okuldan bir eşraf çocuğunu evine göndermesi sonrasında, Kantarcıların Uzun Hüseyin'in “siz ne hakla eşraf çocuğuna sui muamele ediyorsunuz?" (Adıvar 2002: 14) sözleri de olumsuzlamanın genelleştirilmesini gösterir.

Zeyno'nun Oğlu eserinde de yazarın genelleştirmeler yoluyla söylemini meşrulaştırma yoluna başvurduğu görülür. Şeyh M.'nin evinde ikamet eden Haso Çocuk'un yaşadıklarını anlatan yazar, akşam namazından sonra Şeyh'in evinde yaşananları şöyle aktarır:

Küçük rekabetler, ihtiraslar, birbirlerini öldürmeden bırakmayacaklarını zannettiren boğazlaşmalar ve bu boğazlaşmaların nasıl ve niçin olduğu anlaşılmadan canciğer oluşlara inkılap eden tecellileri oluveriyor; siyasiyat, at ve 
çocuğun saf gözlerini bulutlandıran bir şekilde kadından bahsedişler oluyordu. Umumiyetle nargile içiliyor. Bazan da kapıyı iyice kapadıktan sonra bazılarının gözlerini kan çanağına döndüren, dillerini dolaştıran beyaz bir su içiliyordu. Haso Çocuk en çok bu sudan ona içirmek istedikleri zaman korkuyor; bir vesile bulup kaçıyordu (Adıvar 2010: 135).

Halide Edip'in K. Köyü'nde Haso Çocuk'un yaşadıklarını anlatırken de köy halkı ve köyün çocuklarını genelleyerek olumsuzladığı görülür. Yazar, monolojik bir yaklaşımla İstanbul'dan baktığı Diyarbakır'ı, başvurduğu genellemeler yoluyla meşrulaştırarak okuyucuyu ikna etmeye çalışır.

İki eserde de yazar, din adamı, Kürt halkı, eşraf, köyde yaşayan halk/çocuklar, dergâhta yaşayan tarikat mensupları hakkında kendi çizmiş olduğu şablon içerisinde bu kahramanları olumsuzlayarak kendi ideolojik bakışını hedef kitle nezdinde haklılaştırmaya çalışır.

\section{Taslama}

Thompson'un anlam inşa etme sürecinde kullanılabilecek bir yöntem olarak öne sürdüğü taslama, savunulan iddianın hâkim kılınması için birtakım şeylerin "gizlenerek inkâr edilerek veya örtbas edilerek ya da dikkatler mevcut ilişki veya süreçlerden başka yöne çevrilerek" (Thompson 2013: 78) anlatılmasıdır. Bu yöntemde yer değiştirme yoluyla "bir nesne ya da kişiye atıfta bulunmak için kullanılan pozitif veya negatif çağrışımların bir başka yöne aktarılmasıyla” (Thompson 2013: 78) anlam inşa edilebilir. Thompson'un ifade ettiği taslama yönteminin uygulanış tarzlarından birisi de hüsnütabirleştirmedir. Bu tarzla "eylemler, kurumlar ya da toplumsal ilişkiler olumlu bir değerlemeye neden olacak şekilde tarif ya da yeniden tarif edilir." (Thompson 2013: 78). Mecaz da kullanılan bir diğer yöntem olarak sayılabilir. Dilin ya da sembolik biçimlerin temsili bir şekilde kullanılmasını sağlayan mecaz yoluyla "parçayı simgeleyen bir terim bütüne atıfta bulunmak ya da bütünü temsil eden bir terim parçaya atıfta bulunmak için" (Thompson 2013: 78) kullanılır. Mecazla anlam inşasında "gönderge açıkça ifade edilmeksizin ima edilme ya da bir başka şeyle ilişkilendirilerek olumlu ya da olumsuz değerlendirme" (Thompson 2013: 79) stratejisine de 
başvurulabilir. Eğretilemede ise "toplumsal ilişkileri, yerleşik kişi ve grupları gerçekte sahip olmadıkları niteliklerle bahşedilmiş gibi temsil ederek, böylelikle bazı özellikleri diğerleri pahasına vurgulayıp bunlara olumlu ya da olumsuz bir anlam yükleme" (Thompson 2013: 79) yapılarak anlam inşa edilir.

Halide Edip'in Vurun Kahpe'ye eserine verdiği isim yoluyla bir mecaz yapıldığı görülür. Burada vurgulanması gereken kişi Aliye'dir. Aliye, "Hacı Fettah Efendi’nin şeriat uğruna kurban ettirdiği, Kantarcıların Uzun Hüseyin Efendi’nin milliyet namına parçalattırdığı ilk kahpe” (Adıvar 2002: 165) olarak anlatılır. Eserde yüceltilen ve olumlu özellikleriyle ele alınan Aliye "Allahu Ekber" nidalarıyla katledilir. Burada "kahpe" sıfatının onu katleden kişilere yöneltildiği görülür. Bir kişiye veya gruba atfedilen negatif veya pozitif değerlemenin başka bir kişiye aktarılması yöntemiyle mecaz yoluna başvurulmuştur.

Vurun Kahpe'ye eserinde Halide Edip'in birçok yerde Aliye'yi anlatırken hüsnütabirleştirme yöntemine başvurduğu görülecektir. Aliye bir kadın olmasına rağmen sert mizaçlı, güçlü bir karakter sahibi, her zorluğa gögüs gerebilecek bir yapıda anlatılır. Halide Edip'in birçok romanında kendisiyle özdeşleşen kadın karakterler anlattığg bilindiğinden burada Aliye'yi anlatırken kullandığı hüsnütabirleştirme yöntemi buna bağlanabilir. Köyün eşrafından Kantarcıların Uzun Hüseyin Efendi okula geldiğinde "ne bir zaaf, ne gözyaşı, ne de korku gösteren" (Adıvar 2002: 15) Aliye, onu sert bir şekilde okuldan kovar. Bu anlatım Aliye'nin olduğundan daha olumlu bir şekilde anlatıldığını ortaya koyar. Aliye kahramanı eserde oldukça yüceltilmiş, her şeye fedakârca başkaldıran bir yapıda karakterize edilmiştir. Yunan kumandan Damyanos'un karşısına korkusuzca dikilen, köyün eşrafına ve Maarif Müdürü’ne karşı mücadele eden bir kahraman olan Aliye'nin eserde leitmotif olarak kullanılan şu ifadeleri de hüsnütabirleştirme yöntemine örneklik teşkil eder:

Sizin toprağınız benim toprağım, sizin eviniz, benim evim, burası için buranın çocukları için bir ışık, bir ana olacağım ve hiçbir şeyden korkmayacağım, vallahi ve billahi (Adıvar 2002: 1). 
Zeyno'nun Oğlu eserinde yazar, özellikle Mesture Hanım üzerinden bir eğretileme yoluna gittiği görülür. Mesture Hanım ve kızına vermiş olduğu Mazlume isimleri de kahramanların anlatılış tarzlarına bakıldığında bir olumsuzluk yükleme özelliği taşırlar. Mesture Hanım, isminin ifade ettiği anlamın tam zıddı bir hayat tarzına ve düşünceye sahiptir. Kızının üst düzey bir askerle veya bürokratla evlenmesini hayal eder ve bir doktor olan Saffet ile evlenmesine verdiği tepki, onun olumsuz özelliklerinin daha ön plana çıkarılmasını sağlar:

Kızımın istikbalini mahvettiler, sebep olanların gözü kör olsun! İngilizceyi Londralı'dan, Fransızcayı Parisli'den, piyanosunu Hikeler'den öğrenen evladım! İstanbul'un en asri, en şık kızı! Nihayet sünepe, istikbalsiz bir doktorun damına düştü! Ben onu kimlere vermezdim! (Adıvar 2010: 305).

Zeyno'nun Oğlu eserinde anlatılan Zeyno'nun evinde kurulan "kostüm partisi” ile ilgili anlatılanlar, yazarın yanlış batılılaşma mesajları verdiği, bu mesajlarını ise topluluk içinden seçtiği bazı kişileri eğretileme yoluyla anlatarak olumsuz özelliklerini vurguladığı bölümlere örneklik gösterir. Hayri Bey’i anlattığı şu bölüm, onun ne kadar geleneklerine yabancılaşmış ve batı taklitçiliğine düştüğünü gösterir:

Başında üç köşeli bir şapka, arkasında bir ucu sol omzuna atılmış bir harmani, ayaklarında uzun çizmeler vardı. Mahmuzlarını şakırdatarak belindeki ipek kuşağın uçlarını düzelterek kendine aynada çeki düzen veren bu kısa boylu adam Hayri Bey'di. Rudolf Valentino'nun Kanlı Meydan'daki Toreador kostümünü taklit etmişti. Hem de şakaklarındaki favorilere kadar itina ile taklit etmişti. Yalnız Valentino'nun kuvvetli, bülent vücuduna mukabil, Hayri Bey'in çarpuk çurpuk, kısa vücudu, kabadayılığın vahşi ve kanlı bir safhasına ait olan kostümle hayli gülünç olmuştu (Adıvar 2010: 285).

Halide Edip'in kendi fikri söyleminden yola çıkarak monolojik bakış açısıyla olumladı̆̆ı kahramanları hüsnütabileştirme yoluyla yüceltmesi, olduğundan farklı göstermesi, olumsuzladığı/yanlışladığı kahramanların da eğretileme yoluyla olumsuz yönlerini vurgulaması taslama yöntemiyle anlam inşasının gerçekleştiğini gösterir. 


\section{Birleştirme}

Birleştirme yöntemine daha çok bir kimlik inşasının oluşturulmaya çalışıldığ sembolik biçimlerde rastlanır. Bu yöntemin en yaygın kullanımı standartlaştırma şeklinde karşımıza çıkar. Özne tarafından makbul ve doğru görünen kimlik inşası gerçekleştirilmeye çalışılır. Bireyler tek tek ayırt edici özelliklerinden öte, birleştirici ve kolektif bir bilinç etrafında standardizasyona tabi tutulur. "Milli marşlar, bayraklar, çeşitli türde armalar, kitabeler, gibi ulusal bütünlük" (Thompson 2013: 80) sembolleri ile milli bir kimlik inşa edilmeye çalışılır. Sadece "modern ulus devlet gibi büyük ölçekli toplumsal örgütlenmeler örneğinde değil, kolektif bir kimliğin yaratıldığı daha küçük örgütlenmeler örneğinde" (Thompson 2013: 80) de karşılaşılabilir. Bu yöntemle özne "kişileri, farklılıkları ve bölünmeleri hükümsüz bırakacak şekilde kaynaştırma" (Thompson 2013: 80) yoluna başvurabilir.

Halide Edip Vurun Kahpeye ve Zeyno'nun Oğlu eserlerinde "biz" ve "öteki" etrafında bir kimlik inşa eder. "Biz"i temsil eden yapıda Aliye, Tosun Bey, Ömer Efendi, Gülsüm Hala, Zeyno ve Mazlume, Şaban Amca, Haso Çocuk görülürken “öteki”yi temsilen Hacı Fettah Efendi, Kantarcıların Uzun Hüseyin Efendi, Maarif Müdürü, Hatice Hanım, köy halkı, çocuklar, Şeyh M., Mesture Hanım, Ramazan, tarikat mensupları görülür. Vurun Kahpeye romanında Yunan işgaline karşı Kuvay-1 Milliye etrafında bir kimlik inşasının gerçekleşmesi istenilir. Bu kimlik inşasının temsilcisi ise İstanbul'dan köye gelen çağdaş bir kadın öğretmendir.

Halide Edip'in bu eserlerinde "biz" Halide Edip gibi düşünenler ve milli kimliğin yanında duranlardır. "Öteki” ise din adamlarıdır, eşraftır, düşmandır. Halide Edip'in kendisi gibi olanlar bir 1şıktır, korkusuz ve fedakârdır. Fakat “öteki” olanlar menfaatçidir, sefihtir, ahlaksızdır, onursuzdur. Halide Edip böylelikle bir ulus yaratma sürecinde olan Cumhuriyet ideolojisine paralel bir şekilde kimlik inşası yolunda bir misyon üstlenmektedir.

Vurun Kahpeye romanında Mevlit ve Ferdası (Adıvar 2002: 57) bölümünde “biz”in içerisinde yer alan İstanbullu Dede örnek din adamını teşkil eder. Yazar, 
Dede'yi olumlu özellikleri ile anlatarak bir mevlit törenini anlatır. Dede'nin “öteki”si ise Hacı Fettah Efendi'dir. Yazar, sahtekâr, menfaatçi, kinci ve haset bir din adamı olarak karakterize ettiği Hacı Fettah Efendi karşısında, İslam'ın “mistik” yönünü temsil eden Dede etrafinda bir birleştirme yapmaya çabalar.

Aliye'nin çocukları "Senin için ey bayrağımız/Ölürüz de vermeyiz” (Adıvar 2002: 22) marşını meydanda topluca söyleterek dolaştırması da yazarın marş ve bayrak gibi sembollerle bir kimlik inşasına dönük anlam oluşturduğunu gösterir.

\section{Parçalanma}

Parçalanma yönteminde esas olan, "bireyleri bir kolektivite içinde birleştirerek değil, hâkim gruplara etkin bir şekilde meydan okuyabilecek kişi ve grupları parçalayarak veyahut da olası muhalefet güçlerini habis, muzır, ya da tehditkâr" (Thompson 2013: 82) olarak sunmaktır. En tipik stratejisi "farklılaştırmadır-kişi ve gruplar arasındaki ayrımları, farklılıkları ve bölünmeleri vurgulamaktır.” (Thompson 2013: 82). Parçalanma ile birleştirme kimi durumlarda ortak bir strateji olarak görülebilir, çünkü parçalanmada da bir "öteki” ortaya çıkarılır. Burada "öteki”ne sansürlenme uygulanır. Savunulan iddianın karşısında inşa edilen “öteki” sansürlenir, tehdit olarak gösterilir, düşmanlaştırılır.

Halide Edip bu romanlarında Hacı Fettah Efendi ve Şeyh M. kahramanlarından hareketle din adamlarını olumsuz bir tiplemeyle karakterize eder. Hacı Fettah Efendi'nin Aliye hakkında söyledikleri, kimlik inşası önünde nasıl bir tehdit olduğunu gözler önüne serer:

Görüyor musunuz? Erkeklerin içinde yüzü gözü açık namahremler Müslümanların kalbini fesada vermek için şark1 söyleyerek dolaşıyorlar. Bunlar, bunlar mel'undur, bunların eline çocuklarınızı teslim etmeyiniz, eğer bir gün yalnız içimize Yunan girdiğini değil, başımıza taş yağdığını görmek istemiyorsanız, bu karıların üstleri başlarıyla beraber kendilerini de parçalayınız, yoksa Cenab-1 Hakk'ın bütün gazapları üzerimizden eksik olmayacaktır (Adıvar 2002: 23). 
Hacı Fettah Efendi, Aliye gibi çağdaş bir öğretmenin giyim tarzını eleştiren, buna karşı yaptığı eleştirileri ise şeriat üzerinden yapan bir habis, bir tehdit olarak sunulmaktadır. Sosyolojik olarak düşünüldüğünde bir din adamı, köy gibi küçük bir yerleşim yerinde etkin ve aktif olabilecek, insanları kendi fikirleriyle etkileyebilecek bir statüye sahiptir. Yani muktedir fikir ve kimliğe meydan okuyabilecek, tehdit unsuru oluşturabilecek bir konuma sahiptir. Yazar, bu din adamını, yeni ulus kimliğinin oluşumunda tehdit olarak gösterirken onu farklılaştırarak dinini yaşamayan, sahtekâr bir menfaatçi olarak takdim eder.

Zeyno'nun Oğlu eserinde Şeyh M. de hâkim ideolojiye karşı duran, bir tehdit unsuru olarak görülür. Tıpkı Hacı Fettah Efendi'de olduğu gibi bir şeyh de bulunmuş olduğu toplumda saygın ve ağırlığı olan bir konumda düşünülür. Hatta bir din adamının ötesinde onun nüfusu bölgesel, bazen de ulusal nitelikte olabilir. Bu açıdan bakıldığında Şeyh M., ulusal kimlik inşasının karşısında daha büyük bir tehlike olarak tanıtılır. Nasıl bir tehdit unsuru olarak düşünüldüğünü anlamak için şu cümleler açıklayıcı olabilir:

Şeyh, evvela İstanbulluların zalim, günahkâr ve fena insanlar olduklarını, bunları yeryüzünden kaldırmak için Cenab-1 Hakk'ın kendisini memur ettiğini uzun uzadıya anlatmıştı. Bunu o kadar eski ve karışık hikayelerle izah ediyordu ki çocuk şeyhin anlattıklarını tabii olarak masal diye dinliyordu. Bilhassa şeyh, İstanbulluları Kavm-i Lut'a teşbih ediyor, hayatlarından garip misaller alıyordu. Fakat bütün bu ateşli ve renkli nutuklar bir noktaya vasıl oluyordu. Bu asri Kavm-i Lut'u ortadan kaldırmak için Hücum Taburu Kumandanı Hasan Bey'i öldürmek lazımdı (Adıvar 2010: 281-282).

Zeyno'nun Oğlu eserinde Haso Çocuk'a iyilikle muamele eden Şaban Amca, “büyükbabası, Kemah’tan K. Köyü’ne hicret etmiş bir Türk ailesindendi ve Şark Türklerinin sükûnunu, tatlılığını ana tarafindan ateşin bir Kürt kanı almış olmasına rağmen, mizacında muhafaza etmiş, küçük ve zayıf şeylere maddi, manevi kuvvetli erkeklerin hissettiği şefkatle, himaye ile dolu adamdı.” (Adıvar 2010: 70) şeklinde tanıtılarak K. Köyü'ndeki Kürt halkından farklılaştırılır. Bu anlatımla Kürt kanına sahip olmanın, negatif çağrışımlara sebep olabileceği anlatılır.

Farklılaştırılan bir diğer kitle de K. Köyü’nün çocukları ve kadınlarıdır. Halk ve çocuklar, Haso Çocuk'a ve annesi Zeyno'ya insancıl davranmazlar ve onları sürekli 
ötekileştirirler. Haso Çocuk, çocuklar tarafından oyunlara alınmaz ve arkasından sürekli "piç" nidalarıyla çağrılır. Ramazan döndükten sonra, hem annesine hem de Haso Çocuk'a ağır muamelelerde bulunur. Fakat ne köy halkı ne de köyün çocukları onlara yardım etmezler. $\mathrm{Bu}$ kitle, duyarsız, insanlıktan nasibini almamış bireyler olarak tanıtılır. Yazar halkı ve çocukları bu şekilde tanıtarak metinde inşa etmeye çalıştığ kendi fikri konusunda okuyucuyu "biz" etrafında buluşmaya ikna etmeye çalışır.

\section{5. Şeyleştirme}

Şeyleştirme, "sosyo-tarihsel görüngülerin, kalıc1, değişmez ve sürekli tekerrür ediyormuş" (Thompson 2013: 82) gibi resmedilmesiyle uygulanan bir yöntemdir. İnsanlar duygularından arındırılmış, insani melekelerini kaybetmiş şekilde anlatılırlar. “Adlandırma" ve "edilginleştirme" yöntemleriyle iradelerini yitirmiş, nihaileştirilmiş, hareket kabiliyetlerini kullanamayacak şekilde resmedilirler. Bu yöntem, "aktörleri ve eylemliliği siler ve süreçleri, bunları üreten bir öznenin yokluğunda gerçekleşen şeyler veya olaylar olarak temsil ederler. Eylemlerin nasıl başladıklarına dair bütün izlerin kaybolması ve nasıl sonlanacaklarına dair bütün soruların tasavvur edilemez" (Thompson 2013: 82) hale getirilmesi şeklinde işlevsellik kazanır.

Vurun Kahpeye'de romanın bazı yerlerinde halkın bir kısmının Aliye'yi sevdiği görülür. Fakat Hacı Fettah Efendi ve Kantarcıların Uzun Hüseyin Efendi kendi ihtirasları ve nefretleri sebebiyle Aliye'ye hücum ederken köy halkından hiç kimsenin ona sahip çıkmak aklına gelmez. Aliye çocuklara bir şeyler öğretmek adına bütün fedakârlıklara katlanırken halk olanlara hiçbir tepki vermez. Çünkü onlar yazar tarafından “şeyleştirilmiş”lerdir. Bir nesne gibi duygularını yitirmiş, olaylar karşısında tepki veremez duruma düşmüşlerdir.

Zeyno ’nun Oğlu eserinde Kürt Zeyno iradesini kaybetmiş, kendisine yapılanlara tepki veremeyen bir düşkünlükte anlatılır. "Annesinden üç defa daha fazla kuvvetli olmasına rağmen, ona karşı mukavemeti hatırından bile geçiremez." (Adıvar 2010: 59). Köylü kadınlar çeşmeden su alırken ona ve çocuğuna hakaret ederken hiçbir tepki 
veremez konumdadır. Çünkü o yazar tarafindan "makine gibi çalışan, muti ve gürültüden çekinen sessiz bir mâhluk” (Adıvar 2010: 69) olarak tanımlanır. Kürt Zeyno sadece kendisine değil, çocuğuna karşı yapılan hakaretlere, zulümlere de karşılık veremez bir konumdadır. Aksine bir annenin kendisine olmasa bile çocuğuna karşı yapılanlara tepki vermesi beklenirdi.

Haso Çocuk'un başına gelenler de Kürt Zeyno'nunkinden pek farklı değildir. Haso Çocuk, roman boyunca sürekli el değiştirir. Önce Ramazan tarafından kovulur, Şaban Amca'nın evinde kalır, onun hanımı tarafından iyi muamele görmez. Şaban Amca'sının yanında para kazanmaya başlamasıyla Ramazan onu tekrar almak ister fakat at yarışını kazanması sonrasında Şeyh M. onu yanına alır. Tüm bu süreçlerde Haso Çocuk hiçbir tepki veremez. Daha sonra da Hasan ve Zeyno ona yakınlık gösterirler. Haso Çocuk annesinin rahatı için kendisine yapılan haksızlıklara tepki veremez. Bir nesne gibi alınıp konum değiştirilmesine rağmen irade geliştiremeyen bir şekilde anlat1lir.

Vurun Kahpeye romanında mevlit sırasında "şeker verdirilmeyen”, düğünlerde oynatılan ve kötü kadın muamelesi yapılan kadın da nesneleştirilmiş/şeyleştirilmiş kahramanlardan birisidir.

Eserlerin geneline bakıldığında ise genel bir şeyleştirme/nesneleştirmeden bahsetmek gayet tabiidir. Yazarın sesini temsil eden, "biz" etrafinda anlatılan karakterler olumlu özellikleriyle ön plana çıkarken yazarın olumsuzladığı/dışladığ olumsuz kahramanlar, “öteki”ler olumsuz şekilde anlatılır. Olumlu kahramanlarda bir eksiklik veya çelişki, çatışma bulmak söz konusu değildir. Olumsuz kahramanlarda ise hiçbir olumlu emareye rastlanmaz. Bu karakterize etme tarzı şeyleştirme/nesneleştirme yapıldı̆̆ını açıkça gösterir.

\section{Sonuç}

II. Meşrutiye döneminde yazarlığa başlayan ve Cumhuriyet döneminde de eserler yazan bir romancı olan Halide Edip Adıvar, Cumhuriyetin ilanı ile birlikte ulus 
kimliğin inşası yönünde edebi eserler vermiştir. Çalışmamızda incelediğimiz Vurun Kahpeye romanında Yunan işgali sırasında Anadolu'da, Zeyno 'nun Oğlu romanında ise Diyarbakır'da yaşanan Kürt isyanı esnasında Diyarbakır'da geçen olayları konu olarak işler.

Bahtin, romanın şartlarından birini, hayatın çoksesli doğasını yansıtması olarak görür. Bunun yanında dünyanın yazarın gözünden değil de kahramanın gözünden nasıl göründüğünü yansıtma dozunun romana çoksesli veya monolojik niteliği kazandıracağına vurgu yapar. Başarılı bir romanın yaşadığımız hayatta bulunan tüm sesleri orkestralayarak metne dâhil etmesi gerektiğini savunur. Halide Edip'in Vurun Kahpeye ve Zeyno'nun Oğlu romanları öncelikle Bahtin'in söz konusu metodolojisiyle ele alınmış ve yazarın romanlarında çoksesli bir yapının oluşturulamadığı gözlemlenmiştir. Yazar, romanlarında kahramanların gözünden bir dünyayı değil de kendi gözüyle yapılandırdığı dünyada kahramanlarına rol biçer. $\mathrm{Bu}$ eserlerde kahramanlar, kendi öz bilinçleri ve şuurları ile değil, yazarın söylemine katkıda bulunacak şekilde karakterize edilirler. Ayrıca Halide Edip bu romanlarda, hayatın karmaşık yapılanmasını esere dâhil edip orkestralayan bir yazar olarak değil, monolojik bakış açısıyla esere yön veren bir konumda bulunur.

Çalışmanın ikinci aşamasında ise Thompson'un sembolik biçimlerde ideolojik anlam inşa yöntemleri açısından önerdiği metodoloji çerçevesinde eserler tahlil edilmiştir. Thompson, anlam inşa yöntemleri olarak meşrulaştırma, taslama, birleştirme, parçalanma ve şeyleştirme şeklinde bir metodoloji ile sembolik biçimlerin/metinlerin söylem analizinin yapılabileceği üzerinde durur. Bu yöntemler doğrultusunda Halide Edip'in erken dönem Cumhuriyet romancılarının genelinde olduğu gibi, bir ulus inşası yönünde bir yaklaşımı öncelediği görülür. Yazar, kendi dünya görüşünün tek hakikat olduğu görüşünden hareketle eserlerinde monolojik bakış açısıyla kahramanlarını "biz" ve "öteki” şeklinde sınıflama yoluna gitmiştir. Yazarın fikrini yansıtan kahramanlar "biz" etrafında olumlu, yanlışsız olarak anlatılırken "öteki” etrafinda şekillenen kahramanlar olumsuzlayıcı/dışlayıcı bir üslupla ele alınmıştır. Din adamları muktedir 
güç karşısında bir tehdit unsuru olarak romana dâhil edilirken bu kahramanlar sahtekâr, menfaatçi ve dini dünyevi amaçlarına alet eden kahramanlar olarak eserlerde yer alırlar.

Bahtin ve Thompson'un metodolojileri bağlamında yapılan bu çalışmada, Halide Edip'in Vurun Kahpeye ve Zeyno'nun Oğlu eserlerinde romanlarını monolojik bir üslupla kaleme alan Halide Edip'in sesinin/fikrinin/ideolojisinin baskın bir unsur olarak yer aldığ1 görülmüştür. 


\section{KAYNAKÇA}

ADIVAR, Halide Edip (2002). Vurun Kahpeye, İstanbul: Özgür Yayınları.

ADIVAR, Halide Edip (2010). Zeyno'nun Oğlu, İstanbul: Can Yayınları.

BAHTIN, M. Mihail (2004). Dostoyevski Poetikasının Sorunları, çev. Cem Soydemir, İstanbul: Metis Yayınları.

BAKHTIN, M. Mikhail (2014). Karnavaldan Romana-Edebiyat Teorisinden Dil Felsefesine Seçme Yazılar, çev. Cem Soydemir, İstanbul: Ayrıntı Yayınları.

BANARLI, Nihat Sami (2004). Resimli Türk Edebiyatı Tarihi, İstanbul: MEB Yayınları.

BAŞ, Münire Kevser (2013). "Yakup Kadri'nin Romanlarını 'Sosyal Kronik' Olarak Okumak Mümkün Müdür?”, Turkish Studies, (8): 1003-1032.

EAGLETON, Terry (1996). İdeoloji, çev. Muttalip Özcan, İstanbul: Ayrıntı Yayınlar1.

GÜNDÜZ, Osman (2009). “Cumhuriyet Dönemi Türk Romanı”, Yeni Türk Edebiyatı El Kitabı, ed. Ramazan Korkmaz, Ankara: Grafiker Yayınları.

KARPAT, Kemal (2009). Osmanlıdan Günümüze Edebiyat ve Toplum, İstanbul: Timaş Yayınları.

POSPELOV, Gennadiy (2014). Edebiyat Bilimi, İstanbul: Evrensel Basım Yayın.

SEYHAN, Azade (2004). Modern Türk Romanı, çev. Kemal Irmak, İstanbul: İletişim Yayınları.

THOMPSON, John B. (2013). İdeoloji ve Modern Kültür, çev. İdil Çetin, Ankara: Dipnot Yayınları.

TÜZER, İbrahim (2010). “Toplumdan Romana Bir Dönüşümün Hikayesi: Şerif Mardin'in Türk Modernleşmesi”, Ayraç, (7): 61-64. 